\title{
Meta-analysis of the correlation between Helicobacter pylori infection and autoimmune thyroid diseases
}

\author{
Yi Hou ${ }^{1,2, *}$, Wen Sun ${ }^{1, *}$, Chengfei Zhang ${ }^{1,2}$, Tieshan Wang ${ }^{3}$, Xuan Guo ${ }^{1,2}$, Lili Wu ${ }^{3}$, \\ Lingling Qin ${ }^{4}$ and Tonghua Liu ${ }^{1}$ \\ ${ }^{1}$ Key Laboratory of Health Cultivation of the Ministry of Education, Beijing University of Chinese Medicine, Beijing, 100029, \\ People's Republic of China \\ ${ }^{2}$ Dongfang Hospital of Beijing University of Chinese Medicine, Beijing, 100078, People's Republic of China \\ ${ }^{3}$ Beijing Institute of Chinese Medicine, Beijing University of Chinese Medicine, Beijing, 100029, People's Republic of China \\ ${ }^{4}$ Department of Science and Technology, Beijing University of Chinese Medicine, Beijing, 100029, People's Republic of China \\ "These authors contributed equally to this work
}

Correspondence to: Tonghua Liu, email: thliu@vip.163.com

Keywords: helicobacter pylori infection; AITD; meta-analysis

Received: May 26, $2017 \quad$ Accepted: November 14, 2017

Published: December 04, 2017

Copyright: Hou et al. This is an open-access article distributed under the terms of the Creative Commons Attribution License 3.0 (CC BY 3.0), which permits unrestricted use, distribution, and reproduction in any medium, provided the original author and source are credited.

\section{ABSTRACT}

Objective: This study presents a systematic meta-analysis of the correlation between Helicobacter pylori (H. pylori) infection and autoimmune thyroid diseases (AITD).

Materials and Methods: Fifteen articles including 3,046 cases were selected (1,716 observational and 1,330 control cases). These data were analyzed using Stata12.0 meta-analysis software.

Results: H. pylori infection was positively correlated with the occurrence of AITD $(O R=2.25,95 \%$ CI: 1.72-2.93). Infection with $H$. pylori strains positive for the cytotoxin-associated gene A (CagA) were positively correlated with AITD (OR $=1.99$, 95\% CI: 1.07-3.70). There was no significant difference between infections detected using enzyme-linked immunosorbent assay (ELISA) and other methods $(\chi 2=2.151, p$ $=0.143$ ). Patients with Grave's disease (GD) and Hashimoto's thyroiditis (HT) were more susceptible to $H$. pylori infection (GD: OR $=2.78,95 \% \mathrm{CI}: 1.68-4.61$; HT: OR = 2.16, 95\% CI: 1.44-3.23), while the rate of $H$. pylori infection did not differ between GD and HT $(\chi 2=3.113, p=0.078)$.

Conclusions: $H$. pylori infection correlated with GD and HT, and the eradication of $\boldsymbol{H}$. pylori infection could reduce thyroid autoantibodies.

\section{INTRODUCTION}

Autoimmune thyroid diseases are familial autoimmune disorders that are more common in women than men. These diseases include Grave's disease (GD), Hashimoto's thyroiditis (HT), atrophic thyroiditis, and subacute lymphocytic thyroiditis (also known as postpartum thyroiditis, PPT), painless thyroiditis (PT), or silent thyroiditis (ST) [1]. The primary pathological features of autoimmune thyroid diseases are thyroid tissue infiltration of lymphocytes and thyroid dysfunction. Other typical hallmarks of these diseases are thyroid autoantibodies such as thyrotropin receptor antibody (TRAb), anti-thyroglobulin antibody (TGAb), and anti- thyroperoxidase antibody (TPOAb) [2]. The production of these autoantibodies can be attributed to both environmental and genetic factors [3]. Iodine overdose is the primary environmental cause [4], while bacterial and viral infections could be other causative factors $[5,6]$. Cross-reactive antigens can induce superantigen-activated polyclonal $\mathrm{T}$ cells, increase expression of human leukocyte antigen in thyroid tissue and promote other autoimmune tolerance responses [7, 8]. Helicobacter pylori (H. pylori) infection is one of the most common chronic infections worldwide [9]. H. pylori specifically colonizes in the gastric mucosa, inducing chronic inflammation and promoting chronic gastritis, peptic ulcers, and gastric cancer [10]. H. pylori has been reported to be associated 
with other diseases such as diabetes [11], nonalcoholic fatty liver disease [12], iron deficiency anemia [13], and idiopathic thrombocytopenic purpura [14]. The relationship between $H$. pylori infection and AITD has also recently been explored. In 2013, Shi et al. [15] systematically evaluated 7 studies including 862 patients, observing that $H$. pylori infection was associated with the development of AITD in patients with GD but not HT. In this systematic meta-analysis, we further investigated the association between $H$. pylori infection and AITD.

\section{RESULTS}

\section{Characterization of the included studies and method evaluation}

The initial search identified 139 articles that investigated the association between $\mathrm{H}$. pylori infection and AITD, including 119 articles in English and 20 in Chinese. Further examination excluded 110 articles, including 53 review articles, nine duplicated articles, 41 articles with unavailable information, and seven articles without controls, cohort, or cross-sectional surveys. The remaining 29 articles were carefully analyzed. Four articles had a control group that did not consist of healthy individuals, and ten articles with patients in the case group who had other autoimmune diseases, were excluded. Eventually, 15 articles [16-30] including 3,046 patients were selected for meta-analysis (Figure 1). The included studies included cases of GD and HT but no cases of atrophic thyroiditis or subacute lymphocyte thyroiditis. The identified articles were all case-control studies; including six published in Chinese [20, 23, 24, 27-29] and nine published in English [16-19, 21, 22, 25, $26,30]$. These studies included a total of 1,716 patients with AITD and 1,330 control subjects. Seven of these articles were conducted in China [20, 23, 24, 26-29], and eight were completed in other countries [16-19, 21, 22, $25,30]$. Of the 15 included articles, two were abstracts $[16,19]$ and 13 were full texts $[17,18,20-30]$ (Table 1). All the articles had clear inclusion and exclusion criteria. The baseline characteristics of the participants in all the studies were comparable between the observation and control groups, apart from one study [30], in which the age of participants in the observation group was greater than the age of participants in the control group. One included study [18] was conducted on children with an average age of 10.6 years, while the other seven studies $[16,19$, $20,23,24,27,29]$ reported no information on the age of the subjects. In nine studies $[18-20,22,23,25,26,29$, 30] $H$. pylori infection was diagnosed by ELISA. Other methods, such as western blotting, urea breath test (UBT), stool antigen test (SAT), and both ELISA and UBT, were used in the remaining four studies $[16,17,21,24]$. In two studies $[27,28]$, the diagnostic method was not reported. Overall, 11 studies $[16,18,20,21,23-29]$ indicated that
H. pylori infection was associated with AITD, while four studies [17, 19, 22, 30] showed no correlation between H. pylori infection and AITD. Seven of the 15 studies reported that patients were infected with CagA-positive strains of $H$. pylori $[16,17,19,21,22,26,30]$, of which four studies $[16,21,22,26]$ showed that the infection was significantly associated with AITD, and three studies demonstrated no correlation between the infection and AITD [17, 19, 30]. Five studies reported that thyroid autoantibody levels in patients in the observation group were influenced by eradication therapy [20, 24, 27-29]. The logarithm and logarithm standard error of OR value in $H$. pylori infection were utilized to draw the funnel plot, which was symmetrical and was analyzed using Begg's rank correlation method, with $\operatorname{Pr}>|z|=0.656>0.05$, suggesting the absence of publication bias (Figure 2).

\section{Meta-analysis results}

\section{Comparison of $\boldsymbol{H}$. pylori infection rates}

The H. pylori infection rate was reported in 15 studies. As there was heterogeneity among the studies $\left(\mathrm{I}^{2}\right.$ $=61.6 \%, p=0.001$ ), a random model was established. The $H$. pylori infection rates among participants in the observation and healthy control groups were $63.17 \%$ and $45.41 \%$ respectively, indicating that $H$. pylori infection was correlated with AITD (OR $=2.25,95 \% \mathrm{CI}: 1.72-$ 2.93, $p<0.001)$. The relationship between $H$. pylori infection diagnostic method was further investigated by subgroup analysis. In participants diagnosed using ELISA, the infection rate was $61.64 \%$ in the observation group and $45.11 \%$ in the control group $(\mathrm{OR}=2.28,95 \% \mathrm{CI}$ : $1.47-3.55, p<0.001)$. Participants diagnosed using other diagnostic methods had an infection rate of $66.32 \%$ in the observation group and $47.62 \%$ in the control group (OR $=2.16,95 \%$ CI: $1.53-3.05, p<0.001)$. Both subgroup analyses indicated that the infection rate was higher in the observation group than in the control group (Figure 3). There was no significant difference in the rate of diagnosis via ELISA and other methods according to the $\chi^{2}$ test $\left(\chi^{2}\right.$ $=2.151, p=0.143$ ).

Further subgroup analysis revealed that the rate of $H$. pylori infection differed significantly between the GD group (67.29\%) and matched controls (43.09\%, OR $=2.78,95 \%$ CI: $1.68-4.61, p<0.001)$ and the HT group $(62.27 \%)$ and matched controls $(43.22 \%, \mathrm{OR}=2.16$, 95\% CI: $1.44-3.23, p<0.001$, Figure 4). The rate of $H$. pylori infection was not significantly different between participants with GD and HT $\left(\chi^{2}=3.113, p=0.078\right)$.

Due to the observed heterogeneity in statistical results, a sensitivity analysis was performed to investigate the influence of specific research methods. This analysis indicated no significant difference and the conclusions were consistent, indicating that the analysis was stable (Supplementary Figure 1). Meta-regression analysis was 
Table 1: Characterization of included studies and method evaluation

\begin{tabular}{|c|c|c|c|c|c|c|c|c|c|c|c|c|}
\hline \multirow{2}{*}{$\begin{array}{l}\text { Researcher and } \\
\text { date }\end{array}$} & \multirow{2}{*}{ Nation } & \multirow{2}{*}{ Study type } & \multicolumn{2}{|c|}{ Age (years) } & \multirow{2}{*}{$\begin{array}{c}\text { Sex } \\
(\mathbf{F} / \mathbf{M})\end{array}$} & \multirow{2}{*}{$\begin{array}{c}\text { H.pylori } \\
\text { test method }\end{array}$} & \multicolumn{2}{|c|}{ AITD } & \multicolumn{2}{|c|}{ control } & \multirow{2}{*}{$\begin{array}{l}\text { CagA positive } \\
\text { AITD/ control }\end{array}$} & \multirow{2}{*}{$\begin{array}{c}\text { NOS } \\
\text { Quality Score }\end{array}$} \\
\hline & & & AITD & control & & & Нp-Рo & $n$ & Нp-Рo & $n$ & & \\
\hline $\begin{array}{l}\text { Figura N, et al. } \\
1999 \text { [16] }\end{array}$ & Italy & $\begin{array}{l}\text { Case-control } \\
\text { study }\end{array}$ & NR & NR & All women & WB & 32 & 41 & 16 & 33 & $23 / 8$ & unclear \\
\hline $\begin{array}{l}\text { Franceschi F, et } \\
\text { al. } 2004 \text { [17] }\end{array}$ & Italy & $\begin{array}{l}\text { Case-control } \\
\text { study }\end{array}$ & $43.6 \pm 11$ & $44.2 \pm 12$ & $32 / 4$ & UBT & 6 & 16 & 7 & 20 & $3 / 3$ & 4 \\
\hline $\begin{array}{l}\text { Larizza D, et al. } \\
2006[18]\end{array}$ & Italy & $\begin{array}{l}\text { Case-control } \\
\text { study }\end{array}$ & 11.2 & 10 & $130 / 30$ & Elisa & 24 & 90 & 9 & 70 & NR & 6 \\
\hline $\begin{array}{l}\text { Sterzl I, et al. } \\
2006[19]\end{array}$ & Czech & $\begin{array}{l}\text { Case-control } \\
\text { study }\end{array}$ & NR & NR & NR & Elisa & 13 & 60 & 4 & 30 & $5 / 6$ & unclear \\
\hline $\begin{array}{l}\text { Chen LM, et al. } \\
2012[20]\end{array}$ & China & $\begin{array}{l}\text { Case-control } \\
\text { study }\end{array}$ & $35.83 \pm 12.12$ & NR & NR & Elisa & 166 & 246 & 64 & 120 & NR & 8 \\
\hline $\begin{array}{l}\text { Bassi V, et al. } \\
2012[21]\end{array}$ & Italy & $\begin{array}{l}\text { Case-control } \\
\text { study }\end{array}$ & $49.2 \pm 6.9$ & $49.0 \pm 4.5$ & $192 / 20$ & SAT & 71 & 112 & 43 & 100 & $61 / 21$ & 6 \\
\hline $\begin{array}{l}\text { Soveid M, et al. } \\
2012[22]\end{array}$ & Iran & $\begin{array}{l}\text { Case-control } \\
\text { study }\end{array}$ & $35.9 \pm 8.6$ & $37.4 \pm 6.1$ & $159 / 41$ & Elisa & 66 & 88 & 87 & 112 & $43 / 28$ & 6 \\
\hline $\begin{array}{l}\text { Gao Y, et al. } \\
2013 \text { [23 ] }\end{array}$ & China & $\begin{array}{l}\text { Case-control } \\
\text { study }\end{array}$ & NR & NR & $168 / 58$ & Elisa & 98 & 126 & 43 & 100 & NR & 7 \\
\hline $\begin{array}{l}\text { Chen LM, et al. } \\
2013 \text { [24] }\end{array}$ & China & $\begin{array}{l}\text { Case-control } \\
\text { study }\end{array}$ & $33.5 \pm 8.9$ & NR & NR & Elisa, UBT & 84 & 122 & 64 & 120 & NR & 8 \\
\hline $\begin{array}{l}\text { Aghili R, et al. } \\
2013[25]\end{array}$ & Iran & $\begin{array}{l}\text { Case-control } \\
\text { study }\end{array}$ & $34.4 \pm 11.1$ & $34.8 \pm 7.8$ & $66 / 14$ & Elisa & 20 & 43 & 4 & 37 & NR & 6 \\
\hline $\begin{array}{l}\text { Wang Y, et al. } \\
2013 \text { [26] }\end{array}$ & China & $\begin{array}{l}\text { Case-control } \\
\text { study }\end{array}$ & $28 \pm 5.4$ & $26.9 \pm 5.5$ & $181 / 137$ & Elisa & 143 & 216 & 53 & 102 & $75 / 15$ & 7 \\
\hline $\begin{array}{l}\text { Zhao YH, et al. } \\
2014 \text { [27] }\end{array}$ & China & $\begin{array}{l}\text { Case-control } \\
\text { study }\end{array}$ & 45.9 & NR & NR & NR & 96 & 150 & 64 & 150 & NR & 5 \\
\hline $\begin{array}{l}\text { Fei AW, et al. } \\
2014 \text { [28] }\end{array}$ & China & $\begin{array}{l}\text { Case-control } \\
\text { study }\end{array}$ & $40.8 \pm 6.5$ & $40.5 \pm 6.6$ & $212 / 148$ & NR & 120 & 180 & 46 & 100 & NR & 6 \\
\hline $\begin{array}{l}\text { Wang MR, et al. } \\
2015 \text { [29] }\end{array}$ & China & $\begin{array}{l}\text { Case-control } \\
\text { study }\end{array}$ & $35-55$ & NR & NR & Elisa & 98 & 125 & 52 & 125 & NR & 7 \\
\hline $\begin{array}{l}\text { Shmuely H, et al. } \\
2016[30]\end{array}$ & Israel & $\begin{array}{l}\text { Case-control } \\
\text { study }\end{array}$ & $48.3 \pm 16.6$ & $43.5 \pm 16.6$ & All women & Elisa & 47 & 101 & 48 & 111 & $10 / 15$ & 7 \\
\hline
\end{tabular}

Note: AITD, autoimmune thyroid diseases; Elisa, enzyme-linked immunosorbent assay; F, female; Hp-Po, Helicobacter pylori positive; M, male; NR, not reported; SAT, stool antigen test; UBT, urea breath test; WB, western blotting.

performed to determine the heterogeneity in the results, and revealed no heterogeneities among the year and country of publication, sample size, case comparison ratio, or the method used to detect the presence of $H$. pylori (Supplementary Table 1).

\section{Rates of infection with CagA-positive H. pylori strains}

The rates of infection with CagA-positive H. pylori strains were reported in seven studies. Heterogeneity was observed among the rates in these studies $\left(\mathrm{I}^{2}=73.7 \%\right.$, $p=0.001)$. According to random model calculation, the rate of $H$. pylori infection was $34.70 \%$ in the observation group and $18.90 \%$ in the control group $(\mathrm{OR}=1.99,95 \%$ CI: $1.07-3.70, p=0.030)$, indicating that infection with CagA-positive H. pylori strains was associated with AITD (Figure 5). Consistent with this analysis, there was heterogeneity in the statistical results and sensitivity analysis. Systematic evaluation was carried out in a manner similar to that described previously. By excluding the studies by Sterzl et al. [19] and Shumuely et al. [30], the merged effect significantly changed $(\mathrm{OR}=3.35,95 \%$ CI: $2.42-4.64)$ and the heterogeneity disappeared $\left(\mathrm{I}^{2}=\right.$ $0 \%, p=0.653)$, while the conclusion was still consistent
(Supplementary Figure 2). Due to the limitations of the retrieved literature, meta-regression analysis was unable to identify the source of heterogeneity $[31,32]$.

\section{Eradication therapy for thyroid autoantibody levels}

Five studies [20, 24, 27-29] reported the influence of eradication therapy on thyroid autoantibodies. Patients with AITD who had $H$. pylori infection were selected from each study and were randomly allocated to observation and control groups. Only patients in the observation group were treated with eradication therapy. Therefore, meta-analysis could not be performed based on the data provided. The descriptive analysis is shown in Supplementary Table 2.

\section{DISCUSSION}

The correlation between AITD and $H$. pylori infection was studied in 15 publications reporting a total of 3,046 cases. Unlike a previous meta-analysis published by Shi et al. in 2013 [15], which included unhealthy individuals in the control group, and a previous metaanalysis by Luis et al. in 1998 [33], which included 
patients with non-toxic nodular goiter, in this study we included only healthy individuals in the control group. Thyroid nodules were previously reported to be associated with $H$. pylori infection [34]. Atrophic gastritis and/ or chronic $H$. pylori infection in patients with multiple nodular goiters are often treated with an increased dose of thyroxine [35], hence, we excluded studies performed on such patients.

Our results indicated that patients with AITD were more susceptible to $H$. pylori infection $(\mathrm{OR}=2.25,95 \%$ CI: 1.72-2.93), particularly infection with CagA-positive strains of $H$. pylori $(\mathrm{OR}=1.99,95 \% \mathrm{CI}: 1.07-3.70)$. This analysis is consistent with a previous report by Shi et al. $(\mathrm{OR}=1.92,95 \% \mathrm{CI}: 1.41-2.61$; OR $=2.24,95 \% \mathrm{CI}: 1.06$ 4.75]. The CagA gene is present in high-toxicity strains of $H$. pylori and the encoded product, CagA protein, is a marker of gastric mucosal inflammation. CagA is highly immunogenic and promotes local inflammatory cell infiltration [36]. CagA-positive H. pylori strains share a highly identical sequence with thyroperoxidase [37], hence, $H$. pylori infection could induce autoantibody damage to gastric epithelial cells, leading to gastric disease and antigenic antibody cross-reactions causing thyroid tissue damage [38, 39]. Shi et al. indicated that $H$. pylori infection was associated with GD $(\mathrm{OR}=4.35,95 \%$ CI: 2.48-7.64), but showed no significant correlation with HT $(\mathrm{OR}=1.45,95 \% \mathrm{CI}: 0.92-2.26)$. Both GD and HT were included in this study and were associated with $H$. pylori infection in subgroup analysis $(\mathrm{OR}=2.78,95 \% \mathrm{CI}$ : 1.68-4.61; OR $=2.16,95 \% \mathrm{CI}: 1.44-3.23)$. GD and HT share similar pathogenic factors, pathology, biochemistry, and clinical features such as thyroid tissue lymphocyte infiltration resulting in inflammation and TPOAb, TGAb, or increased levels of other thyroid autoantibodies [40]. Thus, H. pylori infection is expected to be associated with GD and HT, which is consistent with the results of our meta-analysis. We also observed that pharmaceutical eradication of $H$. pylori infection reduced levels of thyroid autoantibodies in patients with GD and HT [41]. Patients with AITD who had dysfunctional gastric acid secretion required treatment with higher thyroid hormone levels, indicating that normal gastric acid secretion was necessary for the effective absorption of oral thyroxine [35]. These studies suggest that $H$. pylori infection was associated with the pathogenesis and development of AITD. Our literature review identified no articles reporting the association between atrophic thyroiditis and $H$. pylori infection, while the conclusions from other studies are controversial. Due to the limited number of publications and limited data, the correlation between atrophic thyroiditis and $H$. pylori infection was not analyzed here.

Shi et al. previously reported that $H$. pylori infection diagnosed by ELISA was not associated with AITD. However, we found that regardless of diagnostic test, H. pylori infection was robustly associated with AITD. Although there was great heterogeneity in the merged effects, meta-regression analysis showed that the varieties of diagnostic tools were not responsible for this heterogeneity. Shi et al. attributed the lack of relationship between ELISA-diagnosed H. pylori infection and AITD

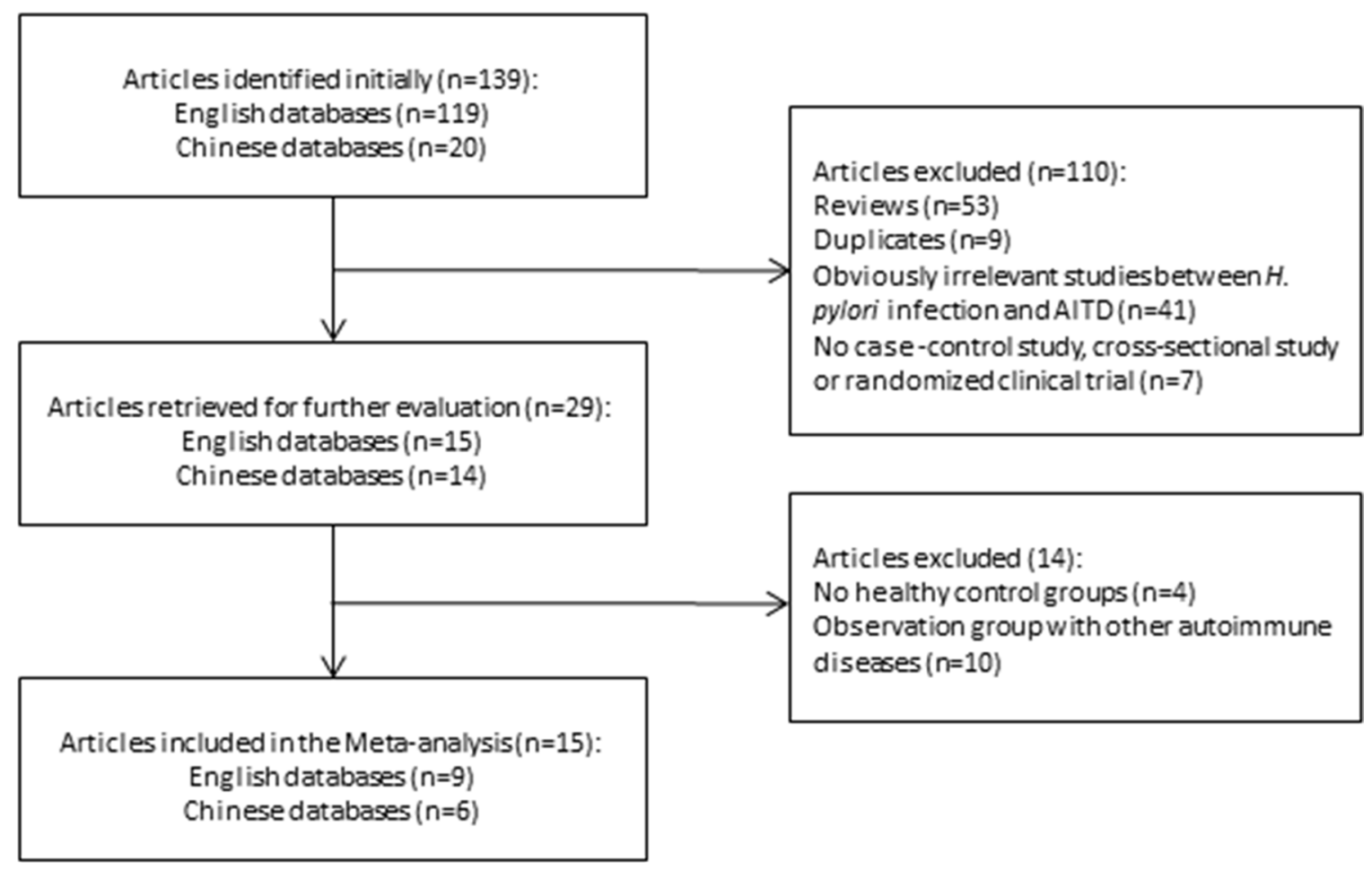

Figure 1: Flow chart of systematic literature review. 
to the inability of this assay to distinguish active from resolved infection, and thus included participants with resolved infection. However, most of the studies that we included did not report a history of AITD. As AITD is a chronic process, H. pylori infection may occur at any stage, which could be either the cause or the consequence of patients susceptible to the infection. Shi et al.'s and our meta-analysis evaluated only whether $H$. pylori infection was associated with AITD without considering whether active infection had any effect on the results.

In conclusion, $H$. pylori infection is associated with AITD. Our results suggest that patients with AITD are more susceptible to $H$. pylori infection, especially infection with CagA-positive strains of $H$. pylori. The high heterogeneity could be influenced by several factors. First, only the abstracts of some included publications were available in standard databases such as PubMed, Web of Science, Ovid Online, etc. [16, 19], limiting the extraction of patient information. In addition, $H$. pylori infection could also be associated with other nongastrointestinal diseases, such as diabetes or autoimmune diseases, but we did not exclude these cases from our analyses [18, 22, 25, 30]. Additionally, in some studies antibiotic use was not ruled out $[18,26]$. These three factors may contribute to the heterogeneity of these studies. Additionally, although the funnel plot suggests no bias, we cannot ignore the potential language or regional bias as we included only manuscripts published in English and Chinese.

\section{MATERIALS AND METHODS}

\section{Inclusion criteria}

Articles or publications including the following information were selected:

(1) Case-control, cohort, or cross-sectional studies in which the number of individuals in the observation group, control group, and number of individuals infected with $H$. pylori, were in either Chinese or English in the abstract or full-text of the publication. (2) The observation groups were diagnosed with AITD. GD was diagnosed according to the following criteria: hyperthyroidism, decreased TSH, increased FT3 and FT4, diffuse enlargement of thyroid tissue, and antibodies against TSH receptor (TRAb) and/ or TPOAb- and TGAb-positivity. HT was diagnosed according to the following criteria: hypothyroidism, increased TSH, decreased FT3, FT4, TPOAb- and TGAbpositivity, typical ultrasonographic features, and evaluation by fine needle aspiration thyroid cytology tests. Atrophic thyroiditis was diagnosed according to the following criteria: hypothyroidism, increased thyroid autoantibodies, and thyroid atrophy features by ultrasound evaluation. PPT was diagnosed according to the following criteria: normal thyroid function before or during pregnancy, abnormal thyroid function within one year after childbirth or abortion, no thyroid pain, low rate of iodine uptake and high blood TPOAb levels, and ultrasound examination revealing diffuse or nodular swelling of the thyroid gland.

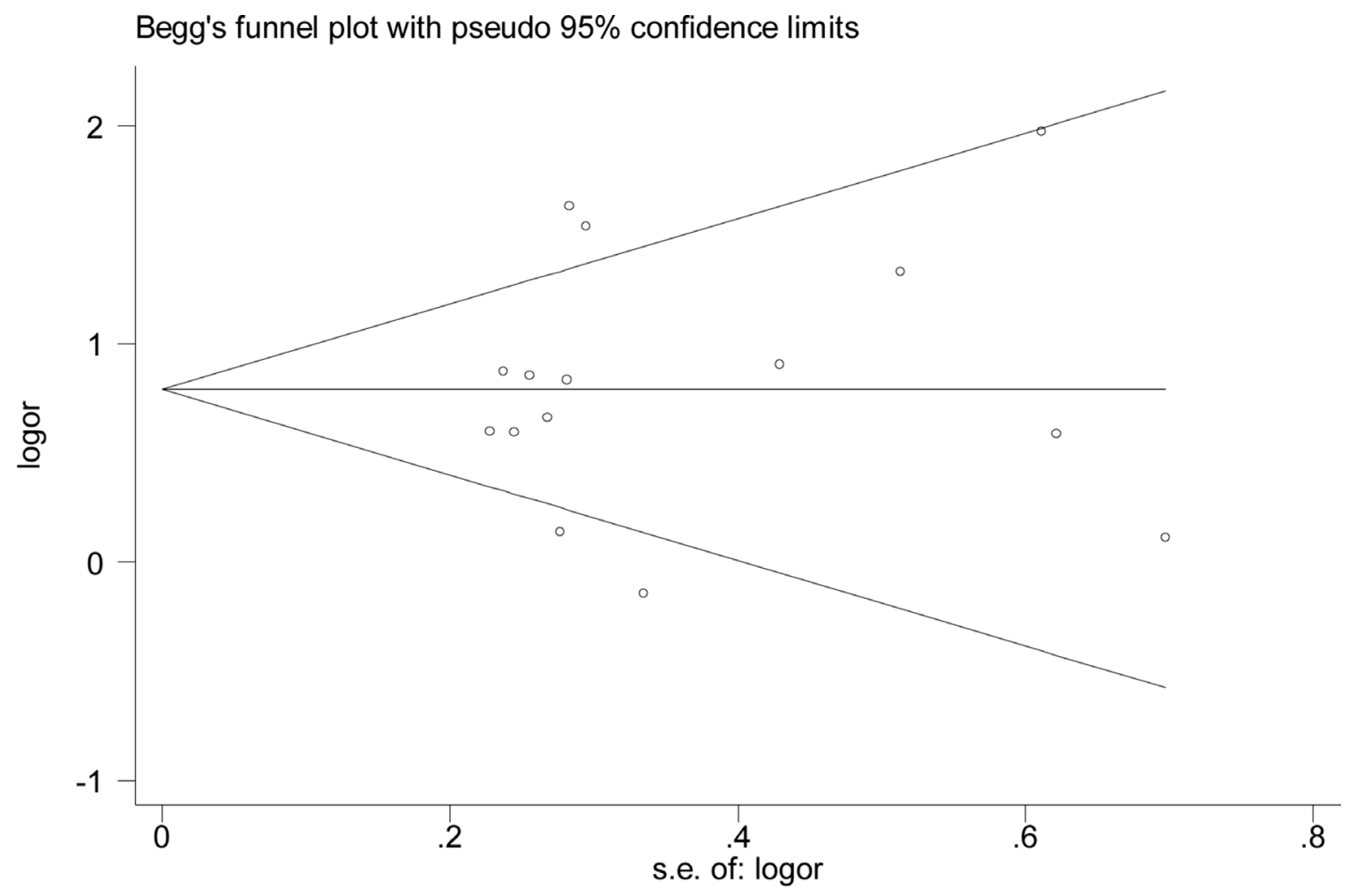

Figure 2: Funnel plot analysis of $H$. pylori infection and autoimmune thyroid diseases. 
PT or ST were diagnosed according to the following criteria: sudden onset hyperthyroidism without pain, low iodine uptake rate and high blood TPOAb, with remission or development of permanent hypothyroidism in 6-12 months, and an ultrasound examination revealing diffuse swelling of the thyroid gland. Control groups included healthy individuals without any autoimmune disease. (3) H. pylori infection was determined by at least one of the following diagnostic methods: stool antigen test, urea breath test, ELISA, or Western blotting.

\section{Exclusion criteria}

Articles or publications were excluded where (1) Insufficient information was provided to support the association of $H$. pylori infection with AITD in the full text publication or abstract where full text manuscripts were not available; (2) The same data was reported in several publications; (3) The study did not include a control group.

\section{Search strategy}

The following databases were searched for articles published before July 2017: PubMed, Medline, Web of Science, OVID, SINOMED, VIP Chinese Science and Technology Journal Full-text Database, Wanfang Data Resources, and CNKI full-text database. English and Chinese search terms included Helicobacter pylori, H. pylori, autoimmune thyroid disease, autoimmune thyroiditis, lymphocytic thyroiditis, Grave's disease, Hashimoto's thyroiditis, atrophic thyroiditis, postpartum thyroiditis, painless thyroiditis, and silent thyroiditis. Where the same data was analyzed by multiple studies, the most recent results were used.

\section{Quality assessment and data extraction}

The quality of the retrieved articles was evaluated independently by two researchers. In case of any disagreement between the researchers, the final decision was made by a third researcher. The quality assessment was followed by the standard "NOS" evaluation recommended by Cochrane [42], including 3 items and 8 articles (population selection, comparability, exposure evaluation, and outcome evaluation) with a maximum score of nine. The results included diagnostic criteria, the case number of both $H$. pylori and CagA-positive

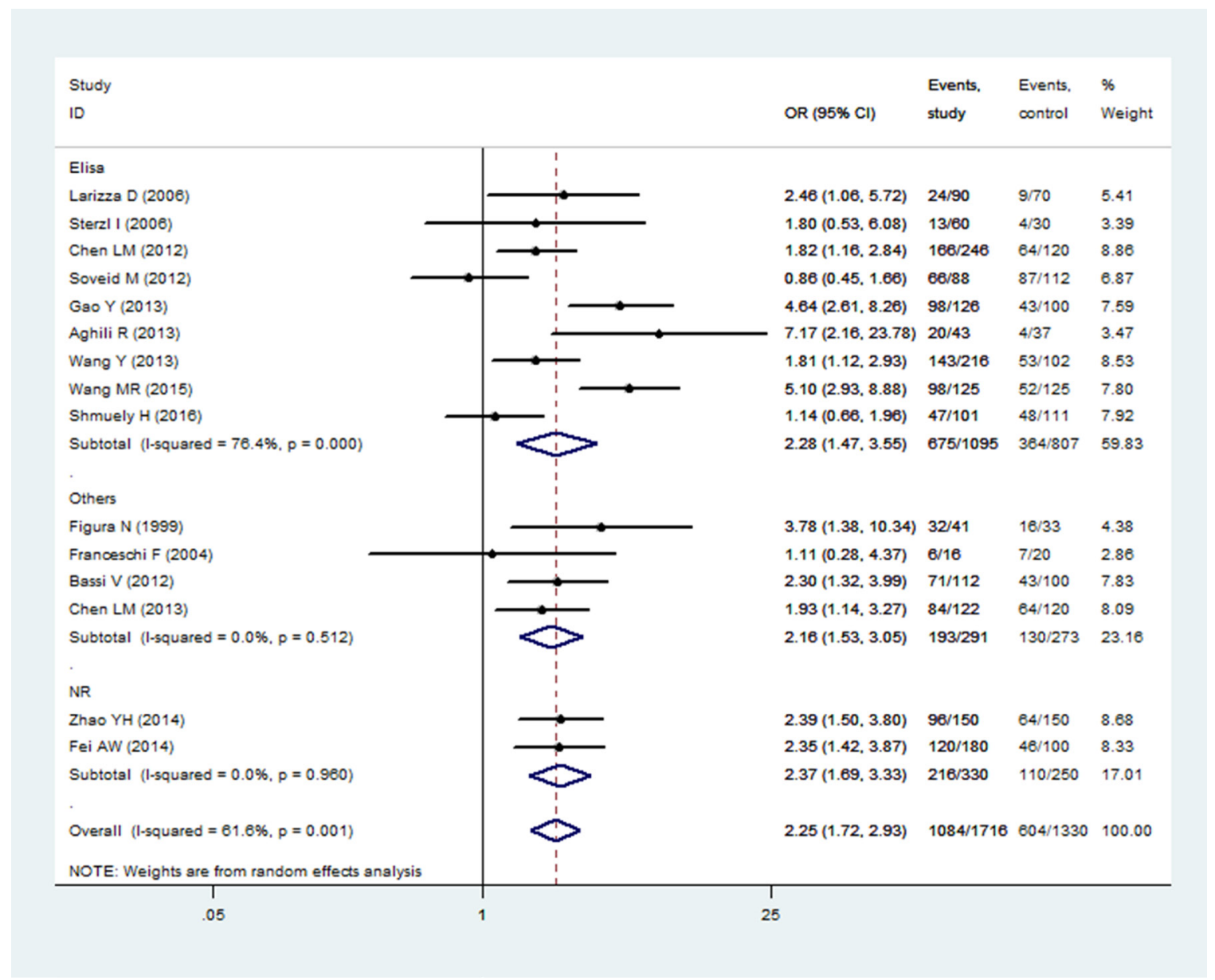

Figure 3: Correlation analysis of $\boldsymbol{H}$. pylori infection with AITD by different detection methods. Note: AITD, autoimmune thyroid diseases; Elisa, enzyme-linked immunosorbent assay; Others, other methods for detecting H. pylori infection; NR, no reported. 


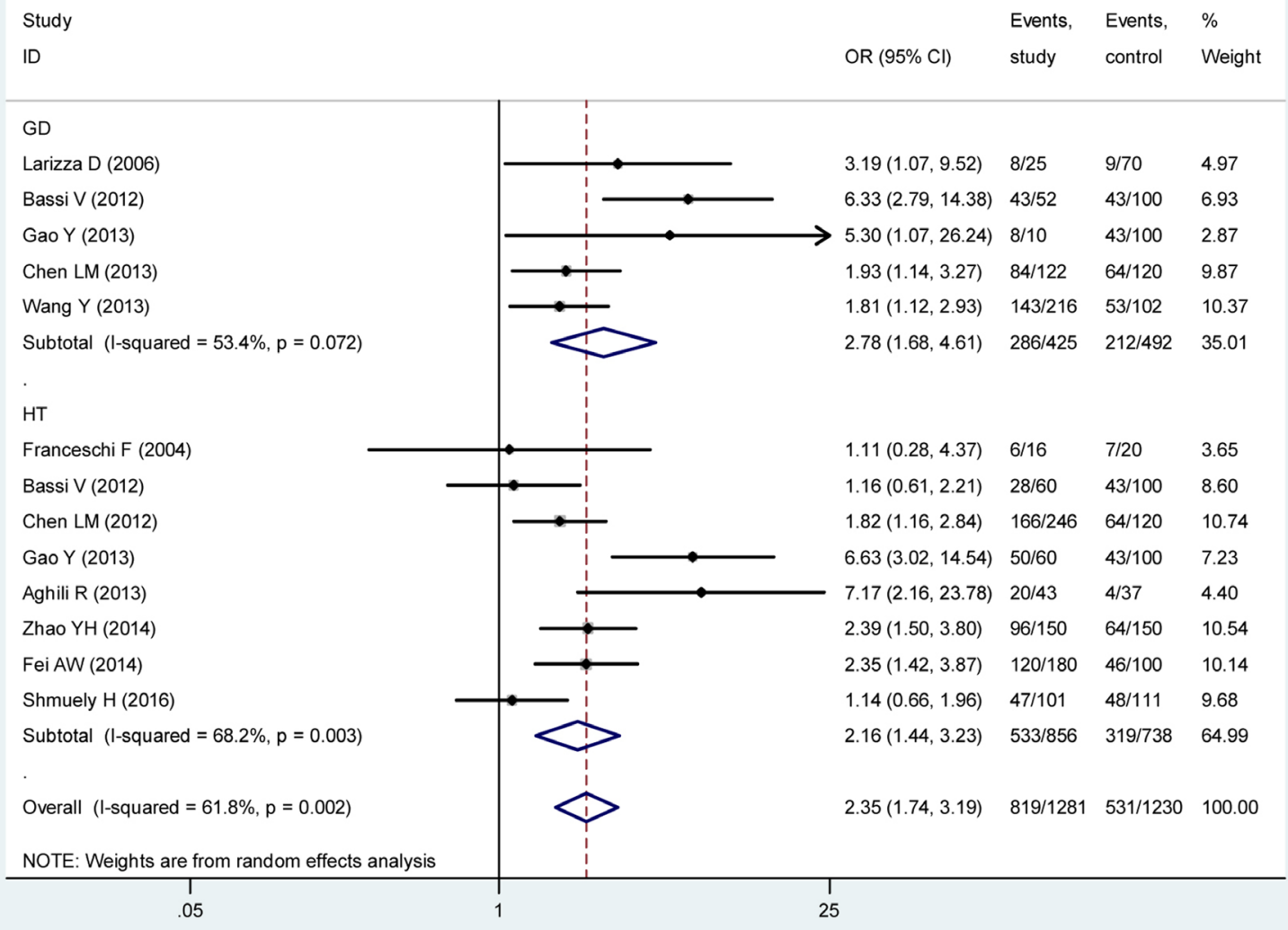

Figure 4: Correlation analysis of $\boldsymbol{H}$. pylori infection with GD and HT. Note: GD, Grave's disease; HT, Hashimoto's thyroiditis.

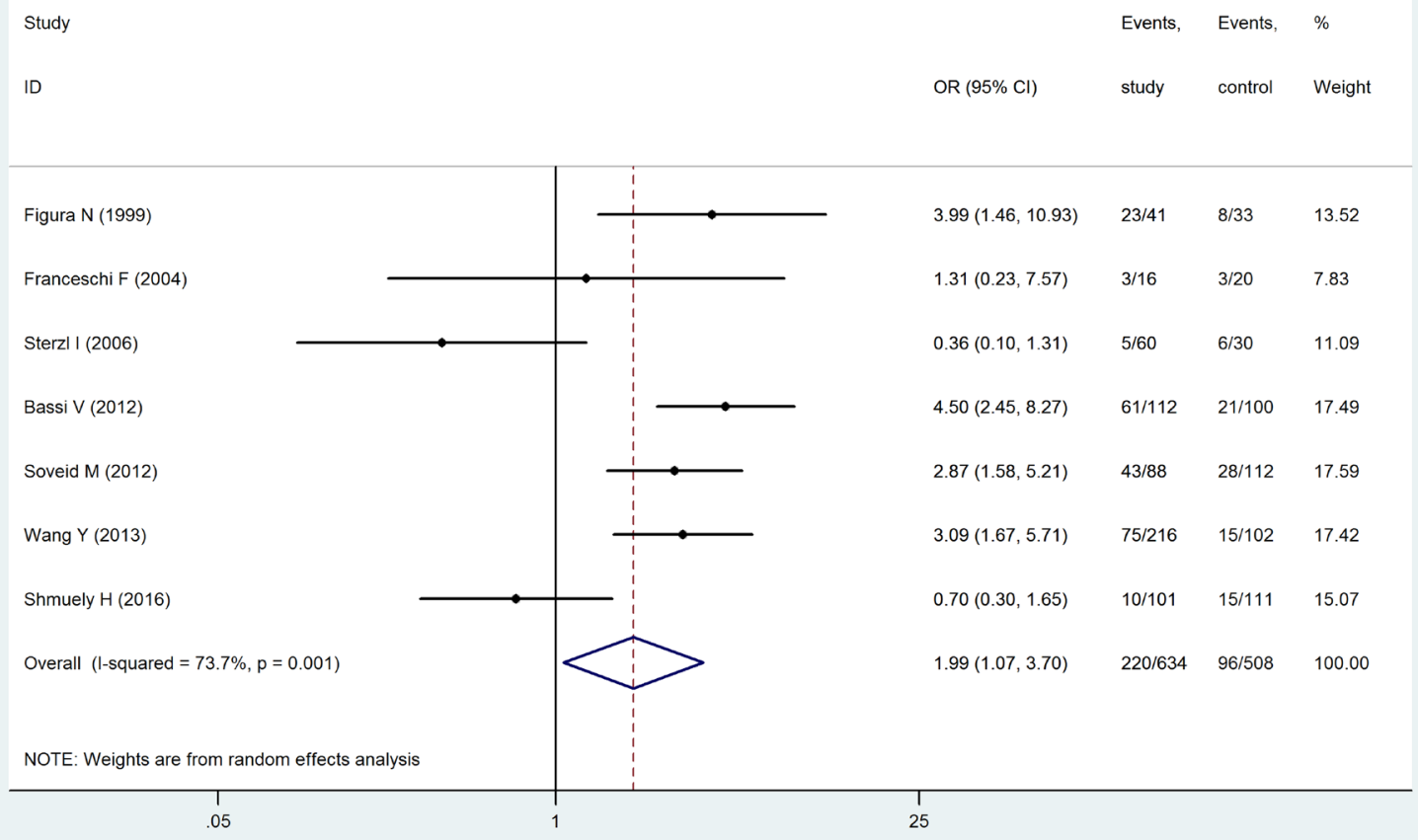

Figure 5: Correlation analysis of infection with a CagA-positive strain of $\mathrm{H}$. pylori, and AITD. 
infections, the sample numbers in observation and control groups, and autoantibody titer after pharmaceutical eradication of $H$. pylori infection.

\section{Statistical process}

Heterogeneity analysis was performed using Stata12.0 processing software. If heterogeneity $\left(\mathrm{I}^{2}>\right.$ $50 \%, p<0.10$ ) was found between studies, a random model was used for further calculation. In the case of no heterogeneity, the fixed effects model was used. The results were presented as the odds ratio (OR) and confidence interval $(95 \% \mathrm{CI})$. Meta-regression analysis was used to identify heterogeneity sources. The stability of the meta-analysis was assessed using sensitivity analysis. If the data provided could not be metaanalyzed, only qualitative analysis by description was provided. An $\chi 2$ test was performed using SPSS16.0 to assess differences between subgroups. The funnel plot and Begg's rank correlation method were used to identify biases in the data.

\section{Abbreviations}

AITD: autoimmune thyroid diseases; CagA: cytotoxin-associated gene A; CI: confidence interval; ELISA: enzyme-linked immunosorbent assay; GD: Grave's disease; H. pylori: Helicobacter pylori; HT: Hashimoto's thyroiditis; NR: not reported; OR: odds ratio; PPT: postpartum thyroiditis; PT: painless thyroiditis; ST: silent thyroiditis; SAT: stool antigen test; TGAb: antithyroglobulin antibody; TPOAb: anti-thyroperoxidase antibody; TRAb: thyrotropin receptor antibody; UBT: urea breath test; WB: western blotting.

\section{Author contributions}

Yi Hou and Wen Sun carried out the systematic evaluation and drafted the manuscript. Chengfei Zhang and Tieshan Wang carried out quality assessment and data extraction. Xuan Guo participated in the quality assessment and data extraction. Lili $\mathrm{Wu}$ and Lingling Qin participated in the design of the study and performed the statistical analysis. Tonghua Liu conceived the study, participated in its design, and coordinated and helped draft the manuscript. All authors read and approved the final manuscript.

\section{ACKNOWLEDGMENTS}

We thank Prof. Yutong Fei for technical assistance.

\section{CONFLICTS OF INTEREST}

All authors declare no conflicts of interest.

\section{FUNDING}

This work was supported by the International Science and Technology Cooperation Project (2015DFA309010): Screening technology and formula optimization on traditional Chinese medicine intervention in Hashimoto's thyroiditis; International Joint Research Center of Prevention and Treatment of Diabetes with Traditional Chinese Medicine by Ministry of Science and Technology of China; Key Laboratory of Health Cultivation of the Ministry of Education; Key Laboratory of Health Cultivation of Beijing (BZ0259); Beijing International Scientific and Technological Cooperation Base for the Prevention; and Treatment of Diabetes with Traditional Chinese Medicine.

\section{REFERENCES}

1. Jiyao W. Internal medicine. The second edition. People's medical publishing house. 2010; 942-963.

2. Baloch Z, Carayon P, Conte-Devolx B, Demers LM, FeldtRasmussen U, Henry JF, LiVosli VA, Niccoli-Sire P, John R, Ruf J, Smyth PP, Spencer CA, Stockigt JR, and Guidelines Committee, National Academy of Clinical Biochemistry. Laboratory medicine practice guidelines. Laboratory support for the diagnosis and monitoring of thyroid disease. Thyroid. 2003; 13:3-126.

3. Balázs C. [The role of hereditary and environmental factors in autoimmune thyroid diseases]. [Article in Hungarian]. Orv Hetil. 2012; 153:1013-22.

4. Yamazaki K, Tanigawa K, Suzuki K, Yamada E, Yamada T, Takano K, Obara T, Sato K. Iodide-induced chemokines and genes related to immunological function in cultured human thyroid follicles in the presence of thyrotropin. Thyroid. 2010; 20:67-76.

5. Gangi E, Kapatral V, El-Azami El-Idrissi M, Martinez O, Prabhakar BS. Characterization of a recombinant Yersinia enterocolitica lipoprotein; implications for its role in autoimmune response against thyrotropin receptor. Autoimmunity. 2004; 37:515-520.

6. Morohoshi K, Takahashi Y, Mori K. Viral infection and innate pattern recognition receptors in induction of Hashimoto's thyroiditis. Discov Med. 2011; 12:505-511.

7. Rapoport B, McLachlan SM. Thyroid autoimmunity. J Clin Invest. 2001; 108:1253-1259.

8. Tomer Y, Davies TF. Infection, thyroid disease, and autoimmunity. Endocr Rev. 1993; 14:107-120.

9. Wang F, Meng W, Wang B, Qiao L. Helicobacter pyloriinduced gastric inflammation and gastric cancer. Cancer Lett. 2014; 345:196-202.

10. Correa P, Piazuelo MB. Helicobacter pylori Infection and GastricAdenocarcinoma. US Gastroenterol Hepatol Rev. 2011; 7:59-64.

11. Chobot A, Bak-Drabik K, Skala-Zamorowska E, Krzywicka A, Kwiecien J, Polanska J. Helicobacter pylori infection 
in type 1 diabetes children and adolescents using ${ }^{13} \mathrm{C}$ urea breath test. Pol J Microbiol. 2014; 63:63-67.

12. Polyzos SA, Kountouras J, Papatheodorou A, Patsiaoura K, Katsiki E, Zafeiriadou E, Zavos C, Anastasiadou K, Terpos E. Helicobacter pylori infection in patients with nonalcoholic fatty liver disease. Metabolism. 2013; 62:121-126.

13. Monzon H, Forne M, Esteve M, Rosinach M, Loras C, Espinos JC, Viver JM, Salas A, Fernandez-Banares F. Helicobacter pylori infection as a cause of iron deficiency anaemia of unknown origin. World J Gastroenterol. 2013; 19:4166-4171.

14. Li X, Sheng G, Xing H. Relationships among HLA-DRB1 Alleles, Helicobacter pylori infection and idiopathic thrombocytopenic purpura in children. Minerva Pediatr. 2015; 67:377-379.

15. Shi WJ, Liu W, Zhou XY, Ye F, Zhang GX. Associations of Helicobacter pylori infection and cytotoxin-associated gene A status with autoimmune thyroid diseases: a meta-analysis. Thyroid. 2013; 23:1294-1300.

16. Figura N, Di Cairano G, Lorè F, Guarino E, Gragnoli A, Cataldo D, Giannace R, Vaira D, Bianciardi L, Kristodhullu S, Lenzi C, Torricelli V, Orlandini G, Gennari C. The infection by Helicobacter pylori strains expressing CagA is highly prevalent in women with autoimmune thyroid disorders. J Physiol Pharmacol. 1999; 50:817-826.

17. Franceschi F, Satta MA, Mentella MC, Penland R, Candelli M, Grillo RL, Leo D, Fini L, Nista EC, Cazzato IA, Lupascu A, Pola P, Pontecorvi A, et al. Helicobacter pylori infection in patients with Hashimoto's thyroiditis. Helicobacter. 2004; 9:369.

18. Larizza D, Calcaterra V, Martinetti M, Negrini R, De Silvestri A, Cisternino M, Iannone AM, Solcia E. Helicobacter pylori infection and autoimmune thyroid disease in young patients: the disadvantage of carrying the human leukocyte antigen-DRB $1^{*} 0301$ allele. J Clin Endocrinol Metab. 2006; 91:176-179.

19. Sterzl I, Hrda P, Potuznikova B, Matucha P, Hana V, Zamrazil V. Autoimmune thyroiditis and Helicobacter pylori-is there a connection? Neuro Endocrinol Lett. 2006; 27:41-45.

20. Chen LM, Lu XM, Xiang W. The relationship between Helicobacter pylori infection and Hashimoto's thyroiditis. Chin J Modern Med. 2012; 50:33-37.

21. Bassi V, Marino G, Iengo A, Fattoruso O, Santinelli C. Autoimmune thyroid diseases and Helicobacter pylori: the correlation is present only in Grave's disease. World J Gastroenterol. 2012; 18:1093-1097.

22. Soveid M, Hosseini Asl K, Omrani GR. Infection by Cag A positive strains of Helicobacter pylori is associated with autoimmune thyroid disease in Iranian patients. Iran J Immunol. 2012; 9:48-52.

23. Gao Y, Liu S. Correlation between Helicobacter pylori infections and autoimmune thyroiditis. Dalian Yike Daxue Xuebao. 2013; 35:160-162.

24. Chen LM, Du LC, Wu XM. Relationship between Helicobacter pylori infection and Grave's disease. Zhejiang Practical Medicine. 2013; 18:85-86.
25. Aghili R, Jafarzadeh F, Ghorbani R, Khamseh ME, Salami MA, Malek M. The association of Helicobacter pylori infection with Hashimoto's thyroiditis. Acta Med Iran. 2013; 51:293-296.

26. Wang Y, Zhu S, Xu Y, Wang X, Zhu Y. Interaction between gene A-positive Helicobacter pylori and human leukocyte antigen II alleles increase the risk of Grave's disease in Chinese Han population: an association study. Gene. 2013; 531:84-89.

27. Zhao YH, Li H, Fan HH. Correlation between Helicobacter pylori infection and Hashimoto's thyroiditis. Zhongguo Yiyuan Ganranxue Zazhi. 2014; 24:1443-1447.

28. Fei AW. Study on the relationship between Helicobacter pylori infection and Hashimoto 's thyroiditis. Med Infant. 2014; 27:168-169.

29. Wang MR, Yao P, Chen BL. Correlation between Helicobacter pylori infections and autoimmune thyroiditis. Zhongguo Yiyuan Ganranxue Zazhi. 2015; 25:1984-1986.

30. Shmuely H, Shimon I, Gitter LA. Helicobacter pylori infection in women with Hashimoto thyroiditis: A casecontrol study. Medicine (Baltimore). 2016; 95:e4074.

31. Higgins J, Thompson S, Deeks J, Altman D. Statistical heterogeneity in systematic reviews of clinical trials: a critical appraisal of guidelines and practice. J Health Serv Res Policy. 2002; 7:51-61.

32. Schmid CH, Stark PC, Berlin JA, Landais P, Lau J. Metaregression detected associations between heterogeneous treatment effects and study-level, but not patient-level, factors. J Clin Epidemiol. 2004; 57:683-697.

33. de Luis DA, Varela C, de La Calle H, Canton R, de Argila CM, San Roman AL, Boixeda D. Helicobacter pylori infection is markedly increased in patients with autoimmune atrophic thyroiditis. J Clin Gastroenterol. 1998; 26:259-263.

34. Shen Z, Qin Y, Liu Y, Lu Y, Munker S, Chen L, Yu C, Chen $\mathrm{P}, \mathrm{Li}$ Y. Helicobacter pylori infection is associated with the presence of thyroid nodules in the euthyroid population. PLoS One. 2013; 8:e80042.

35. Centanni M, Gargano L, Canettieri G, Viceconti N, Franchi A, Delle Fave G, Annibale B. Thyroxine in goiter, Helicobacter pylori infection, and chronic gastritis. N Engl J Med. 2006; 354:1787-1795.

36. Crabtree JE, Covacci A, Farmery SM, Xiang Z, Tompkins DS, Perry S, Lindley IJ, Rappuoli R. Helicobacter pylori induced interleukin-8 expression in gastric epithelial cells is associated with CagA positive phenotype. J Clin Pathol. 1995; 48:41-45.

37. Tomb JF, White O, Kerlavage AR, Clayton RA, Sutton GG, Fleischmann RD, Ketchum KA, Klenk HP, Gill S, Dougherty BA, Nelson K, Quackenbush J, Zhou L, et al. The complete genome sequence of the gastric pathogen Helicobacter pylori. Nature. 1997; 388:539-547.

38. Ma F, Zhao W, Kudo M, Aoki K, Misumi J. Inhibition of vacuolation toxin activity of Helicobacter pylori by iodine, 
nitrite and potentiation by sodium chloride, sterigmatocystin and fluoride. Toxicol In Vitro. 2002; 16:531-537.

39. Moran AP, Prendergast MM, Appelmelk BJ. Molecular mimicry of host structures by bacterial lipopolysaccharides and its contribution to disease. FEMS Immunol Med Microbiol. 1996; 16:105-115.

40. Levine SN. Current concepts of thyroiditis. Arch Intern Med. 1983; 143:1952-1956.

41. Bertalot G, Montresor G, Tampieri M, Spasiano A, Pedroni M, Milanesi B, Favret M, Manca N, Negrini R. Decrease in thyroid autoantibodies after eradication of Helicobacter pylori infection. Clin Endocrinol (Oxf). 2004; 61:650-652.

42. Wells GA, Shea B, O'Connell D, Peterson J, Welch V, Losos M, Tugwell P. The Newcastle-Ottawa Scale (NOS) for assessing the quality of nonrandomised studies in metaanalyses. 2014. http://www.ohri.ca/programs/clinical_ epidemiology/oxford.asp. 